Article

\title{
Tourism and Physical Activity Preferences: Development and Sustainability Strategy
}

\author{
Karel Fromel ${ }^{1,2}$, Michal Kudlacek ${ }^{1, *(1)}$ and Dorota Groffik ${ }^{2}(\mathbb{D}$ \\ 1 Faculty of Physical Culture, Palacký University Olomouc, 77111 Olomouc, Czech Republic; \\ karel.fromel@upol.cz \\ 2 Institute of Sport Science, The Jerzy Kukuczka Academy of Physical Education, 40-065 Katowice, Poland; \\ d.groffik@awf.katowice.pl \\ * Correspondence: michal.kudlacek@upol.cz
}

Received: 29 September 2020; Accepted: 20 October 2020; Published: 23 October 2020

\begin{abstract}
The theoretical foundation of tourism policy is based on an interdisciplinary approach, using evidence-based findings from related scientific fields. For this reason, trends in the health and physical activity of the population should be considered as part of the promotion of healthy lifestyles in the field of tourism. The aim of this study is to support the multidisciplinary development of evidence-based tourism by using the results of long-term monitoring of physical activity (PA) preferences among youth. Furthermore, this study aims to support the continuation of education regarding tourism, behavioral changes in lifestyle, health promotion (including physical activity promotion), physical conditioning, as well as related mental conditioning. An interdisciplinary approach should lead to the adoption of knowledge, habits, and interests that lead to a lifelong readiness to participate in active tourism. The research sample of this 10-year survey consisted of 17,032 Czech and Polish respondents, aged from 12 to 25 years. A questionnaire on physical activity preferences was employed to explore the current status and trends in physical activity preferences and realization. The results show the actual status and trends in preferred and realized types of physical activity and represent an important indicator of tourism service choices for these youths, as well as predict future interests for tourism clients in schools. The analysis of the results enabled the suggestion of a prognostic model of tourism strategy focused on the integration of physical activity with tourism activities.
\end{abstract}

Keywords: tourism strategy; sports tourism; tourism education; health; active lifestyle

\section{Introduction}

Contemporary scientific disciplines strive for interdisciplinarity and the integration of knowledge, theories, research methods, and techniques from various fields of scientific research. The aim is to gather as much evidence-based background as possible, supported by verified evidence-based practices/experiences. The complex relationship between evidence-based and experience-based findings has been discussed in various fields, including medicine [1,2], and in the health, social, and human sciences [3]. For the development of tourism as a scientific field, increasing the importance of the evidence-based element is absolutely crucial. This involves the use of evidence-based knowledge from related social or health sciences. This holds true despite the fact that, according to Karl Popper's philosophical considerations [4], the facts, evidence, or theories used in the area of tourism are more temporally and socially determined, compared with those used in the natural and medical sciences.

The multidisciplinary approach to research is typical of tourism [5,6], health [7], education [8], sport $[9,10]$, and other related social, medical, and natural sciences. The state and understanding of interdisciplinary research in tourism was critically evaluated by Okumus et al. [11], who emphasized the 
importance of cooperating with researchers from other disciplines. Gammon, Ramshaw, and Wright [12] were similarly critical concerning the application of interdisciplinary research in the theory of sport tourism with regard to other disciplines. In this context, Liburd [13] questioned whether we are on the verge of a paradigm shift in the production and consumption of knowledge in tourism research and said that she expects a reconsideration of the research strategy.

Tourism theory and practice should also respond to new facts and the theories derived from related sciences in the context of socioeconomic shifts [14]. It is difficult to provide high-quality tourism while overlooking existing negative trends in societal development, especially in the areas of health and lifestyle and in the field of education. The main causes of these negative trends include, in particular, rates of cardiovascular diseases [15] and mental disorders [16], as well as, relatedly, the declining level of physical activity of the global population [17], including decreasing physical activity (PA) among adolescents $[18,19]$. Worldwide, more than $80 \%$ of adolescents are insufficiently physically active [20]. Moreover, a decrease in participation in organized PA has been observed [21], along with a declining level of muscular fitness [22] and an increase in sedentary behavior [23]. The European Travel Commission [24] emphasized the most important contextual drivers that are shaping consumer change, assessing a number of important changes related to demographic, economic, technological, and environmental factors. The significant changes include the use of new technologies for positive lifestyle changes, new approaches to health promotion and compensation for metal stress, and even lifestyle changes in response to current pandemics. There has been global recognition of the increasing importance of a physically active lifestyle and of related physically active tourism (PAT). Physically active tourism is defined as tourism respecting the need for physical activity, recognizing the emotional, psychosocial, and physical compensating effects of PA. Herein, we use the term "physically active tourism" as defined by its focus on particular physical activities, rather than the commonly used term "active tourism" [25] or broader terms such as "active sport tourism" [26] and "active outdoor sport tourism" [27].

There is still a lack of appreciation of the effects of tourism on human health [28]. Concurrently, there is a need to eliminate the negative effects of certain tourism practices on human health more effectively [29].

These are clear starting points for contributing to positive changes in the lifestyle of the population and emphasizing an evidence-based approach, which should facilitate the development of PAT. An important question is to what extent government policies at the national level underestimate the potential of PAT. Furthermore, Tribe and Xiao [30] posed the following question: Does tourism flexibly respond to widespread sociopolitical changes? Relatedly, Hall and Ram [31] called for the encouragement of walking and active transport in tourism policy, as did Den Hoed [32], in order to use local tourism as a means of maintaining active mobility for seniors. It has also been suggested that cycling transport strategies should respect trends and developments in society [33].

Tourism is one of the largest and fastest growing economic sectors in the world [34,35], and this growth should be reflected in PAT development [36]. PAT aims to achieve the optimal use of PA within the various types of tourism. It represents the creation/preparation of alternative choices and additional physical activities for the population, with the potential to provide further satisfaction through tourism. This idea is related not only to active tourism, but also to sport tourism (i.e., watching sports and attending sports events) and nostalgia sport tourism (i.e., visits to sports museums, famous sports venues, etc.) [37]. With the emphasis on physically active tourism, we propose to expand the sport tourism paradigm, in line with the critical reflections of Gammon et al. [12] and the ideas of Schlemmer et al. [38] about sport tourism versus event tourism.

Physical activity-focused tourism often requires high investments in infrastructure and promotion; hence, the demand for financial returns is high. Therefore, evidence-based and verified facts are essential in order to anticipate the development of tourism. To formulate a longer-term PAT strategy, priority must be given to youth, which enables anticipation of the interests of future young families and 
future adults. In the context of lifelong physical activities, the study of youth theoretically provides the possibility to forecast PAT trends for older age categories in the future.

If negative signs of a lifestyle emerge significantly in childhood and adolescence, it is logical that PAT should be emphasized among families with children, in school environments, and among adolescents. During youth and adolescence, the basis for a physically active lifestyle and for a preference for PAT is formed and adopted. It is therefore worthwhile to examine the role of PAT in the following areas:

(a) Families with children,

(b) School curricula and extracurricular activities,

(c) Out-of-school, institutionalized communities based on sport, ecology, religion, and socially oriented clubs.

PAT cannot delay in responding to the emerging specific interests of customers, and it should anticipate and offer socially desirable, appealing, and sustainable forms of tourism in advance. In the future, marketing will increasingly focus on using predictive analytical methods and algorithms based on new biometric monitoring technologies to provide appropriately targeted offers [24]. Prognostic models, such as predictions of tourist rates in selected countries [34], or more general models, such as the multiple indicator, multiple causes model [39] and the destination imagery processing model [40], should also include input variables regarding PAT, that is, accommodating trends in preferred and popularly practiced types of PA.

The research on PA preferences has not considered associations between preferred PA and tourism activities [41-43]. Trends in PA preferences should be integrated with the objectives of tourism, respected in the designing of school physical education concepts and curricula, and used in the development of extracurricular programs (e.g., sports courses, tours, and project days).

What is the benefit of monitoring adolescents' PA preferences? If these preferences are fulfilled, they become longer-term interests and, to some extent, form the basis of adherence to PA as a part of a healthy lifestyle. They can also be expected to have an influence on adulthood, family life, and healthy and successful aging. Therefore, we pose the following questions:

- Can long-term monitoring of young people's preferred and practiced physical activities be stimulating for the adaptation of tourist services to schools and for a prognostic strategy for their development?

- Which physical activities are the most stable in terms of time, age, and gender, and are suitable for use in tourism?

- How can efforts to promote adequate physical activity in particular tourist activities that are not sports-oriented be supported?

Therefore, the aim of this study is to support the multidisciplinary development of evidence-based tourism using the results of the long-term monitoring of PA preferences among youth. Furthermore, the study aims to support the continuation of education about tourism, behavioral changes in lifestyle, health promotion (including physical activity promotion), and physical conditioning, as well as related mental conditioning. An interdisciplinary approach should lead to the adoption of knowledge, habits, and interests, leading to lifelong readiness for participation in active tourism.

Because of the complexity of this area and wide interdisciplinary nature of the research topic, it is not possible to cover all of the subsequential research topics and recommendations within one paper. Further research is needed to cover mentioned areas (sociodemographic issues, cultural specificities, family affluence scale, geographical aspects, etc.). 


\section{Materials and Methods}

\subsection{Participants}

Research on PA preferences and the types of PA undertaken was conducted from 2009 to 2017. The annual monitoring of PA preferences and PA types practiced took place in schools cooperating with regional universities in all the regions of the Czech Republic and southern Poland. In quota sampling, we respected the ratios of different types of schools, and the sizes of cities and different regions. The different education systems in the Czech Republic and Poland did not allow for a totally identical selection according to grades in schools; thus, selection according to the age of the participants was applied. A total of 17,032 participants participated in the research (Table 1). We excluded 253 respondents because we considered the questionnaires they submitted to be incomplete.

Table 1. Sample characteristics.

\begin{tabular}{|c|c|c|c|c|c|c|c|c|c|}
\hline \multirow{2}{*}{ Characteristics } & \multirow{2}{*}{$n$} & \multicolumn{2}{|c|}{ Age (Years) } & \multicolumn{2}{|c|}{ Weight (kg) } & \multicolumn{2}{|c|}{ Height (cm) } & \multicolumn{2}{|c|}{ BMI $\left(\mathrm{kg} \cdot \mathrm{m}^{-2}\right)$} \\
\hline & & $\mathbf{M}$ & SD & $\mathbf{M}$ & SD & $\mathbf{M}$ & SD & $\mathbf{M}$ & SD \\
\hline Boys, CZ & 7972 & 18.43 & 3.34 & 71.04 & 13.61 & 177.61 & 9.95 & 22.36 & 3.16 \\
\hline Boys, PL & 2546 & 18.42 & 3.38 & 70.52 & 12.63 & 177.96 & 7.64 & 22.18 & 3.20 \\
\hline Girls, CZ & 6688 & 18,40 & 3.12 & 59.11 & 9.52 & 167.09 & 6.93 & 21.12 & 2.85 \\
\hline Girls, PL & 2826 & 18.10 & 3.02 & 57.62 & 8.76 & 167.09 & 6.10 & 21.12 & 2.76 \\
\hline
\end{tabular}

$\mathrm{M}=$ mean, $\mathrm{SD}=$ standard deviation, $\mathrm{BMI}=$ body mass index, $\mathrm{CZ}=$ Czech Republic, $\mathrm{PL}=$ Poland.

\subsection{Instrument and Procedure}

The Questionnaire on Physical Activity Preference (QPAP) was completed under the supervision of stable research teams in the Czech Republic and in Poland, using the online International Database for Research and Educational Support (www.indares.com). The QPAP was standardized for the Czech and Polish conditions $[41,43,44]$. The QPAP involved eight categories: individual PA, team PA, fitness-related PA, water-based PA, outdoor PA, martial arts, rhythm and dance PA, and overall PA. In addition to PA preferences, respondents also answered questions regarding their organized PA, the most frequent PA in summer and winter, and the most preferred PA during the year.

In all categories, respondents selected their top five preferred PAs. Each selected PA received a score based on its ranking. The unselected PAs were scored by the average of the remaining rankings. The final order of preferred PAs was determined by the summary score obtained for their ranking. The trend in PA preference among girls and boys of Czech and Polish origin was documented in two-year periods: 2008-2009 $(n=3184), 2010-2011(n=3746), 2012-2013(n=3230), 2014-2015$ $(n=3834)$, and 2016-2017 $(n=3038)$. In this study, we presented the results of PA preferences in the category of outdoor PA and in the individual PA category. The results of these categories had the highest informative value for the development of PAT. An overview of the most frequent PAs in the summer and winter months was equally important. We selected cycling and downhill skiing as typical summer and winter PAs, respectively, which were the most preferred and most frequently undertaken. The analysis of Czech School Inspections [45] presented cycling tourism and traditional tourism activities as the most commonly realized weekly courses in schools. Meanwhile, water tourism was not so often realized. In total, $73.7 \%$ of schools organized winter ski courses. Based on this analysis, schools used the offer of tourism services, but objective data were lacking. Regarding these typical summer and winter PAs, we also considered the age of the participants according to school cycles (i.e., 12-15 years primary, 16-19 years secondary, and 20-25 years tertiary).

\subsection{Data Analysis}

The statistical analyses were performed using Statistica version 13 (StatSoft, Prague, Czech Republic) and SPSS version 22 (IBM Corp., Armonk, NY, USA). We used descriptive characteristics, cross tables, 
and the Chi-squared test for describing the differences in sport preferences between groups, and the $r$ effect size coefficient $[46,47]$.

\section{Results}

\subsection{Long-Term Trends in Outdoor PA Preferences}

The highest trend stability in preferences of PA (Figure 1), practiced mostly outdoors, was shown by Czech girls in swimming and skating activities and in preferences for cycling and downhill skiing (Figure 1A). The highest increase over time was observed in the preference for hiking and "board" activities (snowboarding, skateboarding, etc.). Polish girls preferred swimming and skating activities the most, and the largest decrease over time was recorded in the preference for cycling and downhill activities (Figure 1B). Czech boys were stable in preferring cycling, swimming, downhill skiing, and skating activities the most. A decline was observed regarding the preference for snowboarding (Figure 1C). Polish boys preferred cycling and swimming activities the most (Figure 1D). The highest increase over time for Polish boys was found in the preference for orienteering activities (compared with Czech boys, activities using modern geoinformation technologies were indicated more often), and a decrease was observed in the preference for downhill activities.

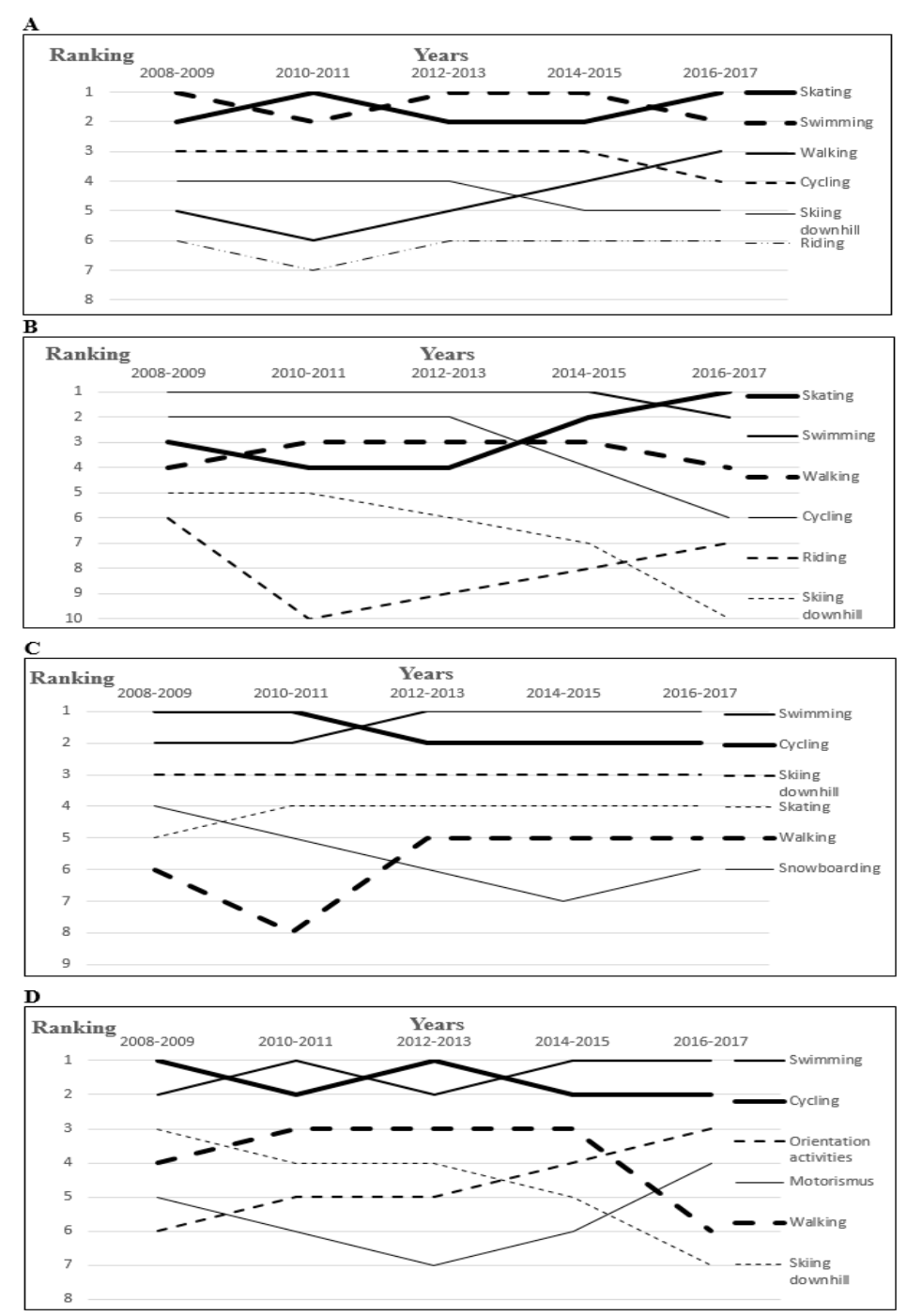

Figure 1. Time trend in preferences of physical activity (PA) practiced mostly outdoors by their ranking. (A) Czech girls $(n=6688)$, (B) Polish girls $(n=2826)$, (C) Czech boys $(n=4972)$, (D) Polish boys $(n=2546)$. 


\subsection{Long-Term Trends in Typically Individual PA Preferences}

Swimming activities were the most preferred individual PAs across all the study groups. Czech girls also preferred cycling, downhill skiing, and skating activities. The highest increase in preferences of Czech girls was recorded in running activities, and the largest decrease for this group was in bowling and squash. After swimming activities, Polish girls preferred skating, running, and gymnastics/rhythm activities the most. A decline was observed in cycling activities. Czech boys preferred cycling and downhill activities, which were ranked just after the most popular activity, swimming. The highest increase was recorded in the preference for running activities and a drop was observed in preferences for table tennis and squash. In addition to swimming, Polish boys preferred cycling, running, and table tennis the most. An increase was found for a preference for gymnastic/rhythm activities, and a decrease was observed for snowboarding.

Swimming and cycling were also the most preferred activities by age (12 to 25 years) for girls and boys from both the countries throughout the survey period. Preferences for hiking and water-based activities increased with age in both Czech and Polish girls, and we observed an increase in preferences for downhill skiing among Polish girls. Preferences for downhill and cross-country skiing and climbing activities increased in Czech boys, and in Polish boys, it was hiking and snowboarding, at the expense of downhill skiing and boat and "board" activities. We observed the greatest decline in preference for rope activities by age among girls and boys in both countries.

\subsection{Most Frequently Practiced Physical Activities during the Year}

The credibility and stability of the sphere of preferences was strengthened by the consistency of the most preferred and most frequently performed PAs throughout the year (in the summer and winter seasons). We found significant differences between Czech girls and Polish girls in the winter season in engagement in downhill skiing/snowboarding $(p<0.001)$ and running $(p=0.016)$, and the Czech girls were involved in these activities more frequently. Swimming $(p<0.001)$, ball games $(p<0.001)$, and skating activities were more prevalent among Polish girls (Table 2). In the summer season, the greatest differences were observed in cycling activities $(p<0.001)$ among the Czech girls, and ball games $(p<0.001)$ and batting games $(p<0.001)$ among the Polish girls.

Table 2. Most frequently practiced physical activities among Czech and Polish girls during the summer and winter seasons.

\begin{tabular}{cccccccc}
\hline & \multicolumn{2}{l}{ Czech Girls } & \multicolumn{3}{c}{ Polish Girls } \\
\hline Summer & \multicolumn{3}{c}{ Winter } & \multicolumn{3}{c}{ Summer } & \multicolumn{2}{c}{ Winter } \\
\hline Physical Activity & $\%$ & Physical Activity & $\%$ & Physical Activity & $\%$ & Physical Activity & $\%$ \\
\hline Running & 16.9 & Downhill skiing and & \multirow{2}{*}{ snowboarding } & Swimming & 16.2 & Downhill skiing and & 17.0 \\
Cycling & 16.1 & Swimming & 9.4 & Running & 16.0 & Swimming & 13.2 \\
Swimming & 15.8 & Running & 8.1 & Ball games & 15.4 & Skating & 9.2 \\
Ball games & 11.0 & Dance & 7.6 & Cycling & 10.9 & Ball games & 8.6 \\
Dance & 7.2 & Muscle strengthening & 7.0 & Batting games & 8.1 & Muscle strengthening & 7.6 \\
Batting games & 5.6 & Ball games & 5.3 & Dance & 7.9 & Dance & 7.0 \\
Hiking & 4.6 & Skating & 4.4 & Skating & 4.2 & Running & 6.9 \\
Skating & 4.2 & & & & & Batting games & 6.8 \\
\hline
\end{tabular}

Significant differences between Czech and Polish boys in the winter season were found in downhill skiing/snowboarding $(p<0.001)$, running $(p<0.001)$, and muscle strengthening $(p<0.001)$, with Czech boys indicating these activities more frequently (Table 3$)$. By contrast, ball games $(p<0.001)$, batting games $(p<0.001)$, and swimming $(p=0.033)$ activities were preferred more often among Polish boys. In the summer season, Czech boys preferred cycling $(p<0.001)$, running $(p<0.001)$, and muscle strengthening $(p<0.001)$ compared with Polish boys, and the latter indicated ball games significantly more often $(p<0.001)$. 
Table 3. Most frequently practiced physical activities among Czech and Polish boys during the summer and winter seasons.

\begin{tabular}{|c|c|c|c|c|c|c|c|}
\hline \multicolumn{4}{|c|}{ Czech Boys } & \multicolumn{4}{|c|}{ Polish Boys } \\
\hline \multicolumn{2}{|l|}{ Summer } & \multicolumn{2}{|l|}{ Winter } & \multicolumn{2}{|l|}{ Summer } & \multicolumn{2}{|l|}{ Winter } \\
\hline Physical Activity & $\%$ & Physical Activity & $\%$ & Physical Activity & $\%$ & Physical Activity & $\%$ \\
\hline Ball games & 25.8 & $\begin{array}{l}\text { Downhill skiing and } \\
\text { snowboarding }\end{array}$ & 25.1 & Ball games & 30.1 & Ball games & 22.1 \\
\hline Running & 16.1 & Ball games & 18.0 & Running & 11.4 & $\begin{array}{l}\text { Downhill skiing and } \\
\text { snowboarding }\end{array}$ & 18.1 \\
\hline Cycling & 15.4 & Muscle strengthening & 13.4 & Cycling & 9.2 & Muscle strengthening & 9.3 \\
\hline $\begin{array}{l}\text { Muscle } \\
\text { strengthening }\end{array}$ & 10.4 & Running & 10.8 & Swimming & 8.5 & Batting games & 8.9 \\
\hline Swimming & 7.4 & Swimming & 6.3 & Batting games & 7.0 & Running & 7.8 \\
\hline Batting games & 6.8 & Batting games & 4.6 & $\begin{array}{l}\text { Muscle } \\
\text { strengthening }\end{array}$ & 6.8 & Swimming & 7.6 \\
\hline
\end{tabular}

\subsection{Preferred Typical Summer (Cycling) and Winter (Downhill Activities) Activities and Those Activities} Practiced by Age

Regarding the typical summer activity (i.e., cycling), we observed a statistically significant decrease in the preference for and practice of cycling among Czech boys $\left(\chi^{2}=9.74, p=0.002, r=0.052\right)$ and Polish boys $\left(\chi^{2}=12.12, p<0.001, r=0.096\right)$ and, vice versa, an increase in Czech girls $\left(\chi^{2}=7.74\right.$, $p=0.005, r=0.042)$ and Polish girls $\left(\chi^{2}=13.21, p<0.001, r=0.099\right)$ (Figure 2).

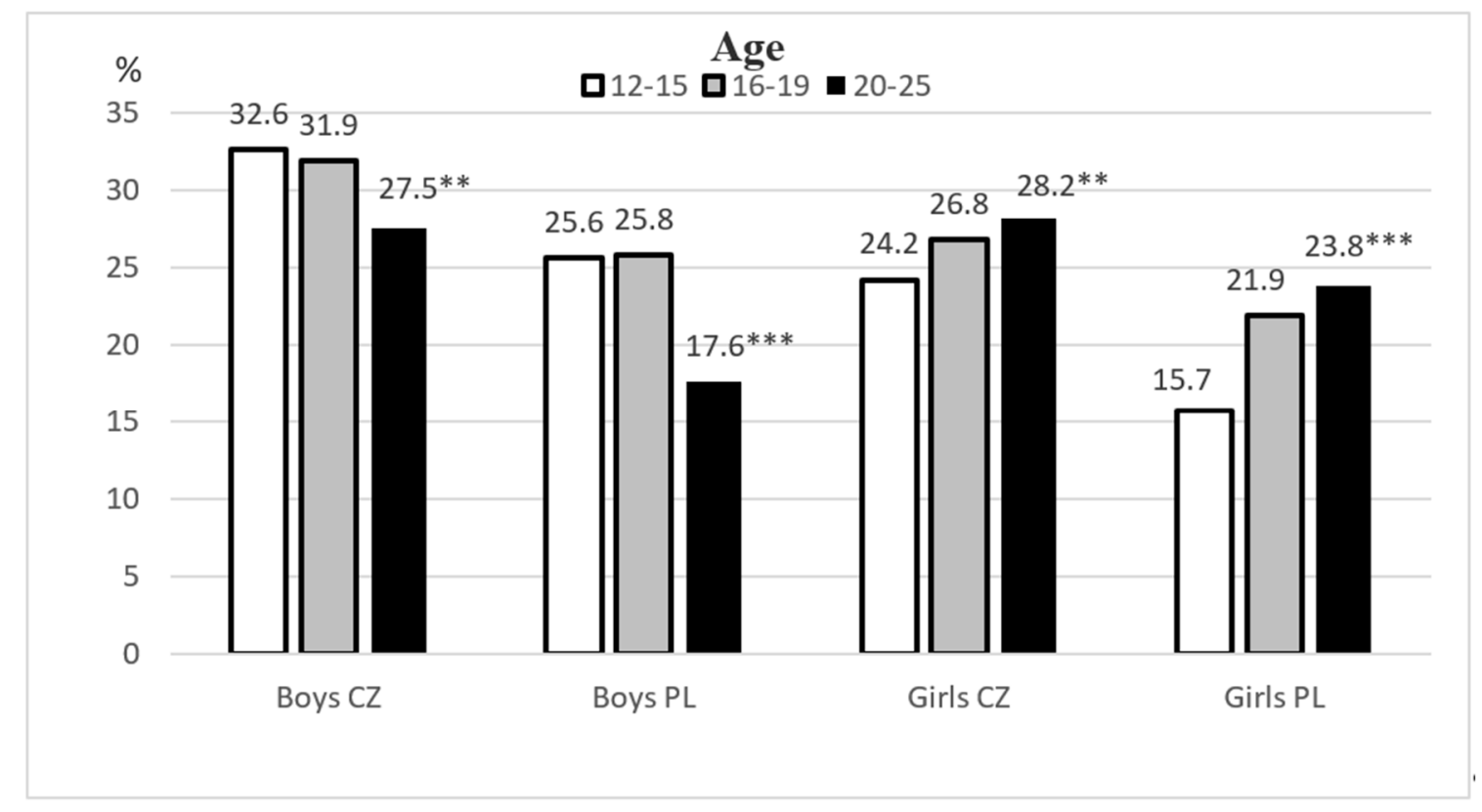

Figure 2. Preferred and concurrently practiced cycling activities among Czech boys and girls (CZ) and Polish boys and girls (PL) by age. A statistically significant difference was observed between 12-15-year-olds and 20-25-year-olds. ${ }^{* *} p<0.01,{ }^{* * *} p<0.001$.

The preference and rate of practicing typical winter downhill activities significantly increased in Czech boys $\left(\chi^{2}=9.81, p=0.002, r=0.052\right)$ and Polish boys $\left(\chi^{2}=18.36, p<0.001, r=0.118\right)$, and also in Polish girls $\left(\chi^{2}=38.17, p<0.001, r=0.169\right)$ (Figure 3). 


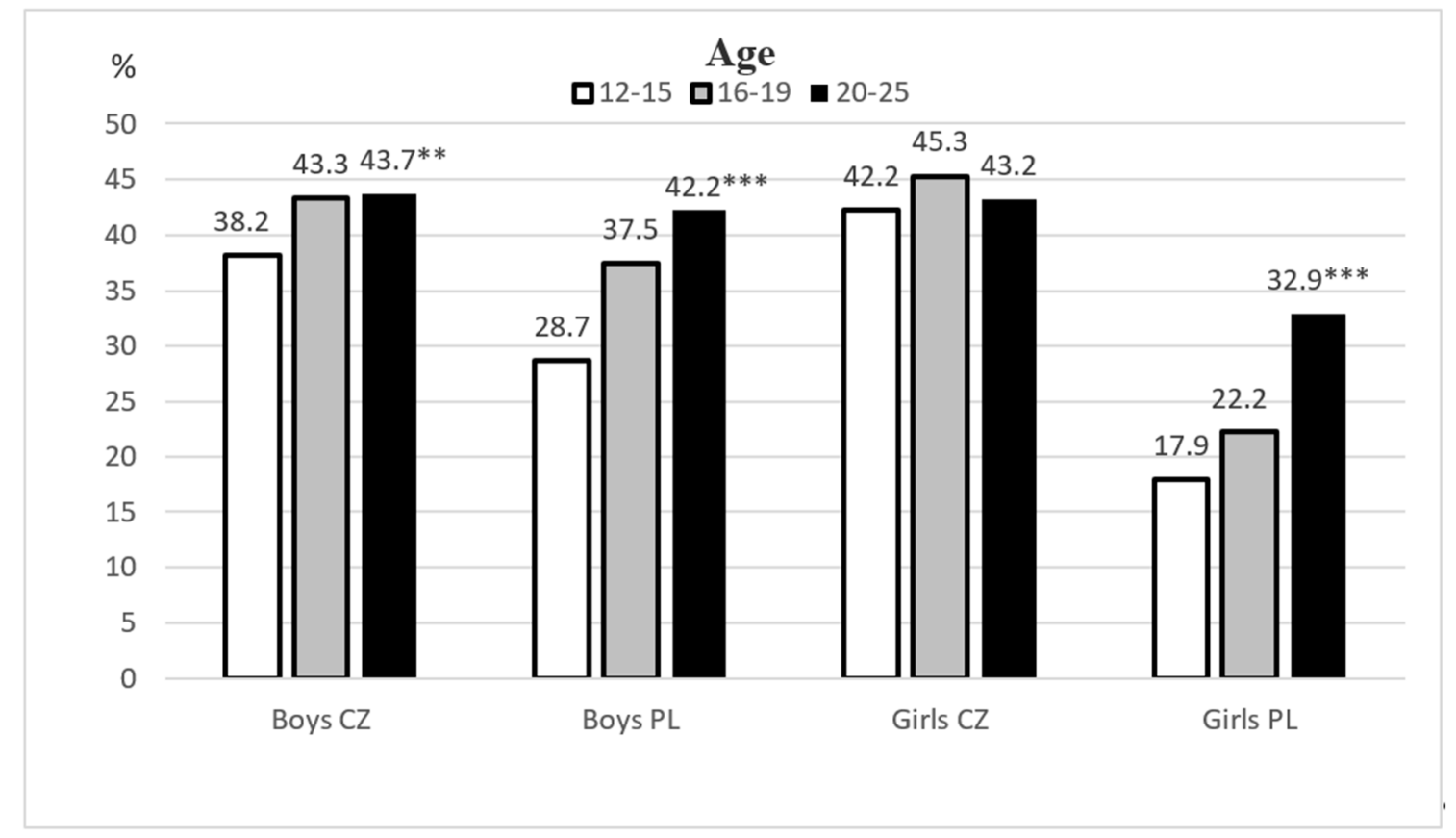

Figure 3. Preferred and concurrently practiced downhill activities by age (CZ-Czech, PL-Polish). A statistically significant difference was observed between 12-15-year-olds and 20-25-year-olds. ** $p<0.01,{ }^{* * *} p<0.001$.

\subsection{A Predictive Model of a Physical Activity-Oriented Tourism Strategy}

Trends in PA preferences predict the success of the selection of physical activity-oriented types of tourism and enable the application of evidence-based tourism strategies. However, many variables (in the form of moderators) interfere with the choice of tourism types based on PA preferences, which may significantly influence the effect of the tourism strategy selection. The simplified predictive model presents the main factors that affect the selection of physical activity-oriented tourism strategies (Figure 4).

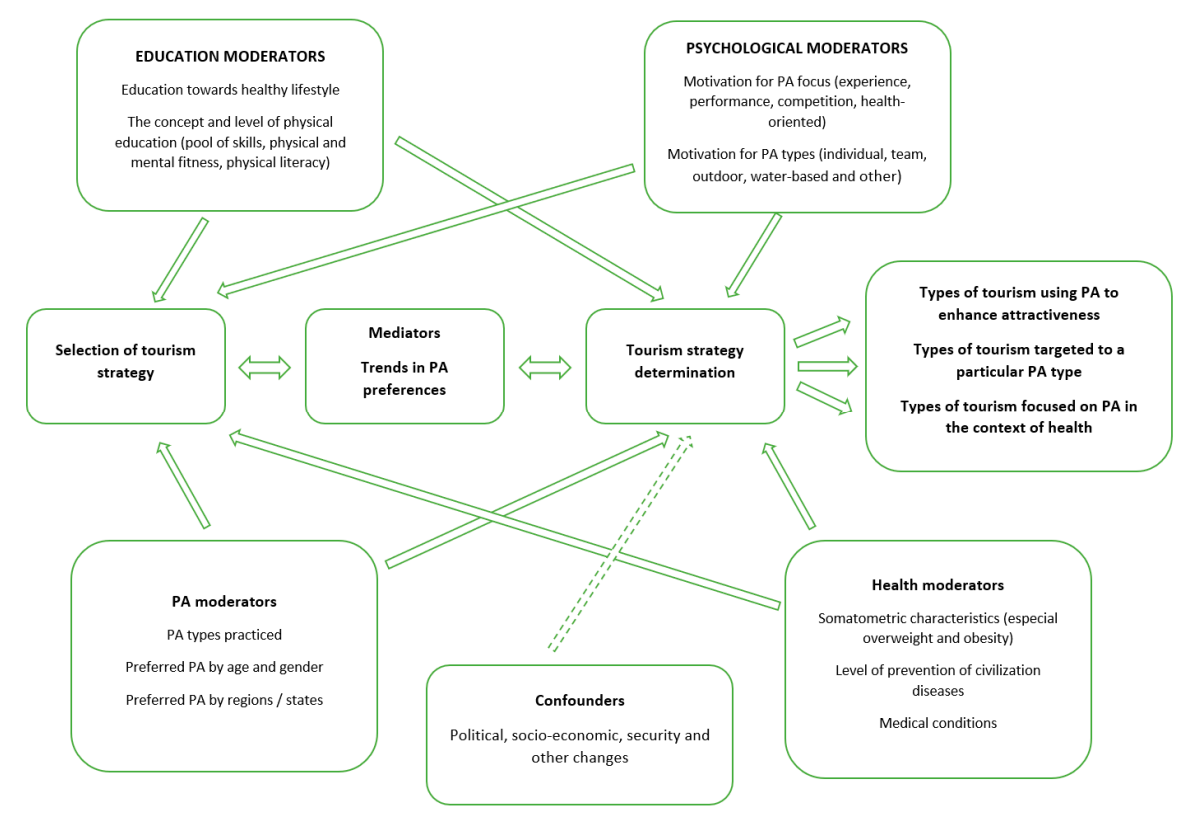

Figure 4. Development of a model of tourism strategy (TS) focusing on physical activity (PA) and accounting for major mediators, moderators, and confounders. 


\section{Discussion}

The main outcome of this study is that long-term trends in PA preferences monitored as a part of this research on youth PA clearly determine the stability, increase, or decrease of preferences regarding particular PA types. These trends can be important predictors of the development of a physical activity-oriented tourism strategy. Evidence has been obtained that preferences for certain types of PA are associated with a higher level of compliance with health-enhancing PA recommendations and higher levels of well-being [41]. These findings are significant for tourism, especially in relation to the contribution of tourism activities to the quality of life and well-being of the participants [48]. Schlemmer et al. [49] argued that the differences between everyday life and holiday situations show how important PA is for the overall satisfaction of tourists. Furthermore, they showed that $7 \%$ of the participants in their study changed their behavior in terms of daily mobility when they returned home, and most of them walked or cycled more often. In this context, we considered the work of Cachón-Zagalaz et al. [50] for an important new approach to PA among young people, in realizing the benefits of combining urban walking with exploring cities.

PA in youth increases the odds of transferring physical activity habits into later life, from families with children, to adulthood, and to older age [51,52]. If preferences for certain types of PA show a long-term tendency and, most importantly, persist with age, young adults will most likely continue to prefer and practice these types of PA in their families, as adults, and in old age. Therefore, respecting the PA preferences of youth and developing the conditions for their successful implementation, including supporting diverse forms of tourism, is a crucial step. It is clear that "generation $\mathrm{Y}^{\text {" will }}$ become the most economically important cohort of future tourism [53].

Agreement regarding preferred and practiced types of PA (e.g., various forms of tourism) is significantly associated with higher rates of youth fulfilling PA recommendations [41]. There is also evidence that day-to-day activities conducted at or around the home are associated with a tendency to participate in similar activities during holidays [54]. In this respect, promotion of "lifelong" PA comes to the fore in conjunction with the increasing interest of elderly individuals in PAT [24], changes in physical activity practices (e.g., e-bike cycling), or technological developments (skiing equipment and resorts). There is sufficient information about the preferences for and rates of practicing tourism activities according to statistics of interest and actual participation in tourism activities of a population [35]. However, these data must be supplemented and confronted with data from related scientific disciplines, including analyses of trends in youth PA preferences. Terzić et al. pointed out the lack of information on tourism preferences of tourists within Europe, as well as the importance of monitoring changes in preferences of sport participants for specific marketing strategies [26].

We found long-term stability regarding preferences for swimming and cycling activities among Czech and Polish boys and girls, which corresponds with our similar research on outdoor PA [41]. The noteworthy preference for downhill skiing-by more than $40 \%$ of Czech boys and girls-is of the same importance. This highlights that the interest in downhill skiing remains high, despite the termination of the compulsory nature of ski courses at schools, which is also confirmed by European statistics. According to European statistics, 22\% of individuals from the Czech Republic and 13\% of individuals from Poland visited ski resorts [55].

Ski courses were obligatory as a part of the curricula at primary and secondary schools in the former Czechoslovak Republic and demonstrably increased the preference for downhill skiing at that time. In the Czech Republic, we recorded an increase in preferences for downhill activities from fifth to second place during the period when ski courses were embedded in the school curricula (2005-2012, according to unpublished results) among 13-14-year-old boys $(n=2961)$ (period of ski courses), with this activity returning to second place at the age of 15 years. In 16-17-year-old boys, the downhill activities jumped to first place and returned to second place at the age of 18. Among girls $(n=3999)$, the position of downhill skiing improved from fifth to fourth place in the 13-14-year-old age group, and in the age category of 16-17, moved from fifth to third place. However, in 18-year-old girls, we observed a return to fifth place in the ranking of preferences. Starting in 2013, ski courses were 
eligible to be included in school education programs, but the final decision is made by schools, which has other economic downsides.

The goal of state health and economic and educational policies should be to make at least one summer and one winter physical activity-oriented course (tourism type), with a duration of at least one week, mandatory in education curricula in as many countries in the European Union as possible, on the basis of PA preferences and trends in tourism development. The importance of such courses, which significantly develop skiing, cycling, and other physical skills, increases in relation to the conclusions of Brey and Lehto [54]. They indicated that skill-challenging activities, in particular, tend to improve the association with the more frequent practice of such activities throughout the year and during holidays. Their next finding - that daily participation in team activities is negatively correlated with participation in these activities during holidays-requires further research. Experience shows that these findings perhaps hold true for boys' most popular sport, football, but not for girls' favorite sport, volleyball. Volleyball has a significantly higher "tourism potential" than various forms of football activities.

Therefore, gender-specific trends must be respected to a further extent in tourism development [56]. This applies to typical team sport activities and to PAs with strong psychosocial effects [57]. PAT can also promote improvements in gender equality, which is something that Pritchard [58] called for in tourism (in the areas of education, research, and practice).

Linking tourism theory with education theory should support making education closer to practical life [59], which has been in effect since times when Comenius [60] promoted the principle of linking education to life. The essence of linking education with practical life, including tourism, is an integral part of education and tourism literacy. Just as cultural literacy can positively influence thinking about tourism [61], physical literacy may significantly affect thinking about tourism in a similar manner. Linking physical and tourism literacy should lead to increases in, for example, awareness of the daily, weekly, or seasonal PA recommendations, the ability to choose the appropriate PA type, awareness of the risks of some sorts of PA, and knowledge of appropriate means to compensate for the health risks associated with traveling. Research exploring the most crucial areas of tourism literacy, in continuity with physical literacy, is desirable for the fields of education, behavioral science, health, and other scientific fields. We observed a similar contribution to environmental education and literacy regarding the development of ecotourism [62] or information literacy for experience-based tourism [63].

There has been an insufficient amount of research regarding the contribution of PAT to meeting PA recommendations and to positive changes in lifestyle. Generally recognized PA recommendations -Healthy People 2010 [64], Healthy People 2020 [65], Physical Activity Guidelines for Americans [66,67], and EU Physical Activity Guidelines [68] — have also mostly focused on shorter daily or weekly cycles. Thus, the focus, for example, on the recommendation for physical activity-oriented multiday activities most related to the possibilities offered by tourism activities has been limited. For the future development of physical activity-oriented tourism, Bouchard, Blair, and Katzmarzyk [69] recommended increasing PA and decreasing the time spent being sedentary, and improving cardio-respiratory fitness levels at all population levels. Thus far, the great weakness of the research is its inability to express the benefits, losses, and risks in tourism, in the context of deteriorating physical fitness or its maintenance. Extending the active and healthy age of the population is a global priority. Tourism has a critical role in these efforts, and it is irreplaceable in many aspects of current lifestyles.

However, the success of PAT dissemination will always depend on respect for the interpersonal and emotional aspects of tourism activities, which are often insufficiently considered [53]. It will also depend on geopolitical factors, which are reflected in attitudes to sports and PA. Sport activities in Central and Eastern European conditions are associated more with performance and competitive sports (sports for all are neglected) compared to Western countries. Therefore, part of the clientele from these countries will reject certain sports activities due to a lack of information but will accept habitual physical activities. We assume that the proposed model of tourism strategy focusing on PA could, in addition to economic [70], geopolitical [71], social cognition [72], active sport [26], active 
outdoor sport event tourism [27], and other models, expand the appropriate business strategy choices in tourism.

\section{Strength and Limitations}

The strength of this study is that it is based on a unique 10-year monitoring of the preferred and practiced types of PA in 12-25-year-old youth in a Central European context, specifically, the Czech Republic and southern Poland, which confirmed the high stability of some lifelong forms of PA in terms of time and age. The theoretical contribution of this study is apparent in the inclusion of trends in the preference for and practice of PA among the important indicators of tourism strategy development and in the design of a prognostic model for the strategy of selecting physical activity-oriented types of tourism. The practical benefit is evident in the overview of the most preferred and most practiced types of PA among youth, specifically identified with respect to gender in a Central European context.

The limitations of this study include the cross-sectional design, the difference in the numbers of respondents in individual years, and, to a certain extent, boys' lower willingness to complete the questionnaires reliably compared with girls. Although the same research team was present at the schools for the eventual explanation of the PA types included in the questionnaire and the possible assignment of similar, new PA types, respondents' answers could have been affected by their overall view of PA types. Thus, further research should focus on economic, educational, behavioral, health, and other benefits from practicing various types of physical activity-oriented tourism. Furthermore, other research should focus on the agreement between the preferences of physical activities and school courses within tourism services and the resulting effect on future life.

\section{Conclusions}

This study aimed, within an interdisciplinary approach, to use evidence from research on physical education and public health in tourism theory and practice. The results present the state and trends in preferred and realized types of PA, which are an important indicator for schools in the choice of tourism services and a predictor of the future interests of tourism clients. The analysis of the results also made it possible to design a prognostic model of tourism strategy, focused on the implementation of PA into tourism activities. The model may form the basis for a clearer constitution of the types of tourism, specifically (a) physically oriented tourism, (b) tourism that uses PA to increase comfort, attractiveness, and well-being, and (c) tourism that uses PA for health benefits. Continuity in the development of physically active tourism, and education in tourism and health promotion, can have a significant economic, psychosocial, and health-improving effect on society.

Because of the complexity of this area and wide interdisciplinary nature of the research topic, it is not possible to cover all of the subsequential research topics and recommendations within one paper. Further research is needed to cover mentioned areas (sociodemographic issues, cultural specificities, family affluence scale, geographical aspects, etc.).

Author Contributions: K.F. conceived, designed, and drafted the manuscript; M.K. acquired and analyzed the data, and performed writing-review and editing; D.G. revised and edited the data and text. All authors have read and agree to the published version of the manuscript.

Funding: The work was supported by the Czech Science Foundation under the grant "Multifactorial research of built environment, active lifestyle, and physical fitness of Czech youth" (No. GA 14-26896S).

Conflicts of Interest: The authors declare no conflict of interest. 


\section{References}

1. Honeybul, S.; Ho, K.M. The role of evidence based medicine in neurotrauma. J. Clin. Neurosci. 2015, 22, 611-616. [CrossRef] [PubMed]

2. Kelly, M.; Morgan, A.; Ellis, S.; Younger, T.; Huntley, J.; Swann, C. Evidence based public health: A review of the experience of the National Institute of Health and Clinical Excellence (NICE) of developing public health guidance in England. Soc. Sci. Med. 2010, 71, 1056-1062. [CrossRef] [PubMed]

3. Oakley, A. Social science and evidence-based everything: The case of education. Educ. Rev. 2002, 54, 277-286. [CrossRef]

4. Popper, K.R. The Logic of Scientific Discovery; Routledge Classics: London, UK, 2002.

5. Darbellay, F.; Stock, M. Tourism as complex interdisciplinary research object. Ann. Tour. Res. 2012, 39, 441-458. [CrossRef]

6. Holden, A. Tourism Studies and the Social Sciences; Routledge: New York, NY, USA, 2005.

7. Saint-Pierre, C.; Herskovic, V.; Sepúlveda, M. Multidisciplinary collaboration in primary care: A systematic review. Fam. Pract. 2018, 35, 132-141. [CrossRef]

8. Roberts, F.S. The challenges of multidisciplinary education in computer science. J. Comput. Sci. Technol. 2011, 26, 636-642. [CrossRef]

9. Button, C.; Croft, J.L. Sports science needs more interdisciplinary, constraints-led research programmes: The case of water safety in New Zealand. Hum. Mov. Sci. 2017, 56, 157-159. [CrossRef]

10. Gonzáles, L.-M.; García-Massó, X.; Pardo-Ibañez, A.; Peset, F.; Devís-Devís, J. An author keyword analysis for mapping sport sciences. PLoS ONE 2018, 13, e0201435. [CrossRef]

11. Okumus, F.; van Niekerk, M.; Koseoglu, M.A.; Bilgihan, A. Interdisciplinary research in tourism. Tour. Manag. 2018, 69, 540-569. [CrossRef]

12. Gammon, S.; Ramshaw, G.; Wright, R. Theory in sport tourism: Some critical reflections. J. Sport Tour. 2017, 21, 69-74. [CrossRef]

13. Liburd, J.J. Tourism research 2.0. Ann. Tour. Res. 2012, 39, 883-907. [CrossRef]

14. Tussyadiah, I.P. Toward a theoretical foundation for experience design in tourism. J. Travel Res. 2014, 53, 543-564. [CrossRef]

15. Wilkins, E.; Wilson, L.; Wickramasinghe, K.; Bhatnagar, P.; Leal, J.; Luengo-Fernandez, R.; Burns, R.; Rayner, M.; Townsend, N. European Cardiovascular Disease Statistics 2017; European Heart Network AISBL: Brussels, Belgium, 2017.

16. Mental Health Foundation. Fundamental Facts about Mental Health 2016; Mental Health Foundation: London, UK, 2016.

17. Katzmarzyk, P.T.; Lee, I.-M.; Martin, C.K.; Blair, S.N. Epidemiology of physical activity and exercise training in the United States. Prog. Cardiovasc. Dis. 2017, 60, 3-10. [CrossRef] [PubMed]

18. Dumith, S.C.; Gigante, D.P.; Domingues, M.R.; Kohl, H.W., III. Physical activity change during adolescence: A systematic review and a pooled analysis. Int. J. Epidemiol. 2011, 40, 685-698. [CrossRef]

19. World Health Organization. Regional Office for Europe. Physical Activity in Adolescents. 2016. Available online: http://www.euro.who.int/_data/assets/pdf_file/0018/303480/HBSC-No.7_factsheet_Physical.pdf? (accessed on 20 January 2020).

20. World Health Organization. Physical Activity. 2018. Available online: http://www.who.int/news-room/factsheets/detail/physical-activity (accessed on 20 January 2020).

21. Lagestad, P.; Mehus, I. The importance of adolescents' participation in organized sport according to $\mathrm{VO}_{2}$ peak: A longitudinal study. Res. Q. Exerc. Sport 2018, 89, 143-152. [CrossRef]

22. Müllerová, D.; Langmajerová, J.; Sedláček, P.; Dvořáková, J.; Hirschner, T.; Weber, Z.; Müller, L.; Derflerová Brázdová, Z. Dramatic decrease in muscular fitness in Czech schoolchildren over the last 20 years. Cent. Eur. J. Public Health 2015, 23, 9-13. [CrossRef]

23. Dalene, K.E.; Anderssen, S.A.; Andersen, L.B.; Steene-Johannessen, J.; Ekelund, U.; Hansen, B.H.; Kolle, E. Secular and longitudinal physical activity changes in population-based samples of children and adolescents. Scand. J. Med. Sci. Sports 2018, 28, 161-171. [CrossRef]

24. European Travel Commission. Lifestyle Trends and Tourism. How Changing Consumer Behaviour Impacts Travel to Europe; European Travel Commission: Brussels, Belgium, 2016; p. 25. 
25. Vila, N.A.; Brea, J.A.F.; de Araújo, A.F. Health and sport. Economic and social impact of active tourism. Eur. J. Investig. Health Psychol. Educ. 2020, 10, 70-81. [CrossRef]

26. Terzić, A.; Demirović, D.; Petrevska, B.; Limbert, W. Active sport tourism in Europe: Applying market segmentation model based on human values. J. Hosp. Tour. Res. 2020, 20, 1-23. [CrossRef]

27. Perić, M.; Vitezic, V.; Badurina, J.D. Business models for active outdoor sport event tourism experiences. Tour. Manag. Prespect. 2019, 32, 100561. [CrossRef]

28. Bauer, I.L. Improving global health-Is tourism's role in poverty elimination perpetuating poverty, powerlessness and 'ill-being'? Glob. Public Health 2017, 12, 45-64. [CrossRef]

29. Clift, S. Tourism and health: Current issues and future concerns. Tour. Recreat. Res. 2000, 25, 55-61. [CrossRef]

30. Tribe, J.; Xiao, H. Developments in tourism social science. Ann. Tour. Res. 2011, 38, 7-26. [CrossRef]

31. Hall, C.M.; Ram, Y. Measuring the relationship between tourism and walkability? Walk score and english tourist attractions. J. Sustain. Tour. 2018, 27, 223-240. [CrossRef]

32. Den Hoed, W. Where everyday mobility meets tourism: An agefriendly perspective on cycling in The Netherlands and the UK. J. Sustain. Tour. 2019, 28, 185-203. [CrossRef]

33. Nilsson, J.H. Urban bicycle tourism: Path dependencies and innovation in Greater Copenhagen. J. Sustain. Tour. 2019, 27, 1648-1662. [CrossRef]

34. Hassani, H.; Silva, E.S.; Antonakakis, N.; Filis, G.; Gupta, R. Forecasting accuracy evaluation of tourist arrivals. Ann. Tour. Res. 2017, 63, 112-127. [CrossRef]

35. Publications Office of the European Union. Tourism Satellite Accounts in Europe; Publications Office of the European Union: Luxembourg, 2017. [CrossRef]

36. Szczechowicz, B. The importance of attributes related to physical activity for the tourism product's utility. J. Sport Tour. 2012, 17, 225-249. [CrossRef]

37. Gibson, H. Towards an understanding of 'why Sport tourists do what they do'. Sport Soc. 2005, 8, 198-217. [CrossRef]

38. Schlemmer, P.; Barth, M.; Schnitzer, M. Research note sport tourism versus event tourism: Considerations on a necessary distinction and integration. J. Conv. Event Tour. 2020, 21, 1-9. [CrossRef]

39. Park, S.; Hahn, S.; Lee, T.; Jun, M. Two factor model of consumer satisfaction: International tourism research. Tour. Manag. 2018, 67, 82-88. [CrossRef]

40. Cardoso, L.; Dias, F.; de Araújo, A.F.; Marques, M.I.A. A destination imagery processing model: Structural differences between dream and favourite destinations. Ann. Tour. Res. 2019, 74, 81-94. [CrossRef]

41. Fromel, K.; Kudlacek, M.; Groffik, D.; Svozil, Z.; Simunek, A.; Garbaciak, W. Promoting healthy lifestyle and well-being in adolescents through outdoor physical activity. Int. J. Environ. Res. Public Health 2017, 14, 533. [CrossRef]

42. Křen, F.; Kudláček, M.; Wasowicz, W.; Groffik, D.; Frömel, K. Gender differences in preferences of individual and team sports in Polish adolescents. Acta Univ. Palacki. Olomuc. Gymn. 2012, 42, 43-52. [CrossRef]

43. Kudláček, M.; Frömel, K.; Groffik, D. Gender differences in preferences of martial arts in Polish adolescents. Arch. Budo 2015, 11, 227-234.

44. Groffik, D.; Frömel, K.; Mitáš, J.; Garbaciak, W.; Svozil, Z. Formative action self-research: Promoting tertiary sport and physical education based on evidence and experience-based approaches. J. Phys. Educ. Sport 2018, 18, 434-444. [CrossRef]

45. Česká Školní Inspekce. Vzdělávání v Tělesné Výchově, Podpora Rozvoje Tělesné Zdatnosti a Pohybových Dovedností [Education in Physical Education, Support for the Development of Physical Fitness and Movement Skills]; Česká Školní Inspekce: Praha, Czech Republic, 2016.

46. Cohen, J. Statistical Power Analysis for the Behavioral Sciences, 2nd ed.; Lawrence Erlbaum Associates: Hillsdale, NJ, USA, 1988.

47. Sheskin, D.J. Handbook of Parametric and Nonparametric Statistical Procedures, 4 th ed.; Chapman \& Hall/CRC: Boca Raton, FL, USA, 2007.

48. Li, T.E.; Chan, E.T.H. Diaspora tourism and well-being: A eudaimonic view. Ann. Tour. Res. 2017, 63, $205-206$. [CrossRef]

49. Schlemmer, P.; Blank, C.; Bursa, B.; Mailer, M.; Schnitzer, M. Does health-oriented tourism contribute to sustainable mobility? Sustainability 2019, 11, 2633. [CrossRef] 
50. Cachón-Zagalaz, J.; Lara-Sánchez, A.J.;Ubago-Jiménez,J.L.; deMesa, C.G.-G.; López-Gallego, FJ.;Zagalaz-Sánchez, M.L. Walk more towards active leisure, tourism, culture, and education. Sustainability 2019, 11, 3174. [CrossRef]

51. Itoh, H.; Kitamura, K.; Hagi, N.; Mashiko, T.; Matsukawa, T.; Yokoyama, K. Leisure-time physical activity in youth as a predictor of adult leisure physical activity among Japanese workers: A cross-sectional study. Environ. Health Prev. Med. 2017, 22, 37. [CrossRef]

52. Telama, R.; Yang, X.; Viikari, J.; Välimäki, I.; Wanne, O.; Raitakari, O. Physical activity from childhood to adulthood: A 21-year tracking study. Am. J. Prev. Med. 2005, 28, 267-273. [CrossRef] [PubMed]

53. Cohen, S.A.; Prayag, G.; Moital, M. Consumer behaviour in tourism: Concepts, influences and opportunities. Curr. Issues Tour. 2014, 17, 872-909. [CrossRef]

54. Brey, E.T.; Lehto, X.Y. The relationship between daily and vacation activities. Ann. Tour. Res. 2007, 34, 160-180. [CrossRef]

55. Vanat, L. 2018 International Report on Snow and Mountain Tourism; Laurent Vanat: Geneva, Switzerland, 2018.

56. Jucan, M.S.; Jucan, C.N. Gender trends in tourism destination. Procedia Soc. Behav. Sci. 2013, 62, 437-444. [CrossRef]

57. Clarc, H.J.; Camiré, M.; Wade, T.J.; Cairney, J. Sport participation and its association with social and psychological factors known to predict substance use and abuse among youth: A scoping review of the literature. Int. Rev. Sport Exerc. Psychol. 2015, 8, 224-250. [CrossRef]

58. Pritchard, A. Gender and feminist perspectives in tourism research. In The Wiley Blackwell Companion to Tourism; Lew, A.A., Hall, C.M., Williams, A.M., Eds.; John Wiley \& Sons: Malden, MA, USA, 2014; pp. 314-324. [CrossRef]

59. Mair, H.; Sumner, J. Critical tourism pedagogies: Exploring the potential through food. J. Hosp. Leis. Sport Tour. Educ. 2017, 21, 195-203. [CrossRef]

60. Comenius, I.A. Scholarum Reformator Pansophicus; Státní pedagogické nakladatelství: Praha, Czech Republic, 1956.

61. Johnson, P.C. Cultural literacy, cosmopolitanism and tourism research. Ann. Tour. Res. 2014, 44, $255-269$. [CrossRef]

62. Fang, W.-T.; Lien, C.-Y.; Huang, Y.-W.; Han, G.; Shyu, G.-S.; Chou, J.-Y.; Ng, E. Environmental literacy on ecotourism: A study on student knowledge, attitude, and behavioral intentions in China and Taiwan. Sustainability 2018, 10, 1886. [CrossRef]

63. Stamboulis, Y.; Skayannis, P. Innovation strategies and technology for experience-based tourism. Tour. Manag. 2003, 24, 35-43. [CrossRef]

64. U.S. Department of Health and Human Services. Healthy People 2010: Understanding and Improving Health; U.S. Department of Health and Human Services: Washington, DC, USA, 2000. Available online: https://www.cdc.gov/nchs/healthy_people/hp2010.htm (accessed on 20 January 2020).

65. U.S. Department of Health and Human Services. Healthy People 2020; U.S. Department of Health and Human Services: Washington, DC, USA, 2010. Available online: https://www.cdc.gov/nchs/healthy_people/hp2020. htm (accessed on 20 January 2020).

66. U.S. Department of Health and Human Services. Physical Activity Guidelines for Americans, 2nd ed.; U.S. Department of Health and Human Services: Washington, DC, USA, 2018. Available online: https://whish. stanford.edu/wp-content/uploads/2019/01/2018-Physical_Activity_Guidelines_2nd_edition.pdf (accessed on 20 January 2020).

67. U.S. Department of Health and Human Services. 2018 Physical Activity Guidelines Advisory Committee Scientific Report; U.S. Department of Health and Human Services: Washington, DC, USA, 2018. Available online: https:/health.gov/news-archive/blog-bayw/2018/03/2018-physical-activity-guidelines-advisorycommittee-submits-scientific-report/index.html (accessed on 20 January 2020).

68. European Commission. EU Physical Activity Guidelines: Recommended Policy Actions in Support of Health -Enhancing Physical Activity; Education and Culture DG: Brussels, Belgium, 2008.

69. Bouchard, C.; Blair, S.N.; Katzmarzyk, P.T. Less sitting, more physical activity, or higher fitness? Mayo Clin. Proc. 2015, 90, 1533-1540. [CrossRef]

70. Schubert, S.F.; Schamel, G. Sustainable tourism development: A dynamic model incorporating resident spillovers. Tour. Econ. 2020. [CrossRef] 
71. Lee, C.C.; Olasehinde-Williams, G.; Akadiri, S.S. Geopolitical risk and tourism: Evidence from dynamic heterogeneous panel models. Int. J. Tour. Res. 2020, 1-13. [CrossRef]

72. Seow, A.N.; Choong, Y.O.; Moorthy, K.; Choong, C.K. Predicting medical tourism behavioural intention using social cognition models. Tour. Rev. 2020. [CrossRef]

Publisher's Note: MDPI stays neutral with regard to jurisdictional claims in published maps and institutional affiliations.

(C) 2020 by the authors. Licensee MDPI, Basel, Switzerland. This article is an open access article distributed under the terms and conditions of the Creative Commons Attribution (CC BY) license (http://creativecommons.org/licenses/by/4.0/). 